\title{
Do changes in the water regime determine the abundance of the copepod trophic group in a Neotropical floodplain?
}

\author{
Mudanças no regime das águas determinam a abundância de grupos tróficos de \\ copépodes em uma planície de inundação Neotropical?
}

Lenin Medeiros de Almeida Lino ${ }^{1}$ (D), Tatiane Mantovano ${ }^{1}$ (D), Vanessa G. Tibúrcio ${ }^{2}$ (D),

\section{Fábio Amodêo Lansac-Tôha}

${ }^{1}$ Programa de Pós-graduação em Ecologia de Ambientes Aquáticos Continentais - PEA, Núcleo de Pesquisas em Limnologia Ictiologia e Aquicultura - Nupélia, Universidade Estadual de Maringá UEM, Av. Colombo, 5790, 87020-900. Maringá, PR, Brasil

${ }^{2}$ Programa de Pós-graduação em Biologia Comparada, Núcleo de Pesquisas em Limnologia Ictiologia e Aquicultura - Nupélia, Universidade Estadual de Maringá - UEM, Maringá, PR, Brasil.

*e-mail: mantovano.t@outlook.com

Cite as: Lino, L. M. A., Mantovano, T., Tibúrcio, V. G., Lansac-Tôha, F. A. Do changes in the water regime determine the abundance of the copepod trophic group in a Neotropical floodplain? Acta Limnologica Brasiliensia, 2021, vol. 33, e102.

Abstract: Aim: Our study evaluated the effects of extreme weather events and environmental conditions on the trophic groups of copepods (herbivores and omnivores) in the upper Paraná River floodplain. Methods: The zooplankton were collected and Copepods and Rotifers were analyzed in nine environments of the upper Paraná River floodplain during 2000 and 2010, during which time the La Niña (drought) and El Niño (flood) climatic events occurred, respectively. Results: The results suggest that in periods of extreme drought productivity-related variables act as determining forces on abundance of copepod trophic groups due to the contraction of aquatic ecosystems. Although the abundance of trophic groups is associated with system productivity, the responses between them differ, since herbivore abundance was associated with chlorophyll- $a$ and total phosphorus and omnivores with rotifer abundance. In extreme flood (El Niño), no significant relationship was found between environmental variables and any trophic group. Conclusions: In general, it is believed that in periods of extreme drought the variables associated with productivity act as determining forces on the abundance of trophic groups of copepods due to the contraction of aquatic ecosystems. According to the results found, it is suggested that other works be carried out with a greater number of extreme events to corroborate our results and, and also to extrapolate to other aquatic communities.

Keywords: climate events; microcrustaceans; trophic guilds; floodplain.

Resumo: Objetivo: Nosso estudo avaliou os efeitos de eventos climáticos extremos e condiçóes ambientais sobre os grupos tróficos (herbívoros e onívoros) de copépodes na planície de inundação do alto rio Paraná. Métodos: O zooplâncton foi coletado e copépodes e rotíferos foram analisados em nove ambientes da planície de inundação do alto rio Paraná, durante os anos de 2000 e 2010, períodos que ocorreram os eventos climáticos La Niña (seca) e El Niño (cheia), respectivamente. Resultados: Os resultados sugerem que em períodos de seca extrema (La Nińa) as variáveis associadas a produtividade atuem como forças determinantes sobre a abundância de grupos tróficos de copépodes devido a contração dos ecossistemas aquáticos. As respostas entre as abundâncias dos grupos tróficos 
divergem apesar de estarem associados a produtividade do sistema, uma vez que a abundância de herbívoros está associada a clorofila- $a$ e ao fósforo total e dos onívoros à abundância de rotíferos. No período de cheia extrema (El Niño) não foi encontrada relação significativa entre as variáveis ambientais e grupos tróficos. Conclusóes: Acredita-se que em períodos de extrema seca as variáveis associadas à produtividade atuam como forças determinantes na abundância de grupos tróficos de copépodes devido à contração dos ecossistemas aquáticos. De acordo com os resultados encontrados, sugere-se que outros trabalhos sejam realizados com maior número de eventos extremos para corroborar com nossos resultados e, ainda para extrapolar para outras comunidades aquáticas.

Palavras-chave: eventos climáticos; microcrustáceos; grupos tróficos; planície de inundação.

\section{Introduction}

Floodplains are ecosystems formed by distinct aquatic, terrestrial and transitional environments that have peculiar physical, chemical and biological characteristics (Junk et al., 1989; Agostinho et al., 2004; Tundisi \& Matsumura-Tundisi, 2008). They are generally characterized by high species diversity due to habitat heterogeneity and their significant structural and functional complexity (Tockner et al., 2000; Ward et al., 2002). In these systems, the hydrological cycle is one of the main factors that regulate the structuring of aquatic communities, marked by the flood pulse (Thomaz et al., 2007).

Changes in the flood pulses in these environments can be caused by two factors: dams, which control downstream flow (Souza-Filho \& Stevaux, 2002), and weather events, such as ENSO (El NiñoSouthern Oscillation), which may increase or decrease the river level due to the intensity of rainfall in Neotropical regions. The term ENSO is used to describe the interactions between the Southern Oscillation Index (OS) and La Niña and El Niño episodes (Stenseth et al., 2003). This index is a difference in atmospheric pressure between the Central and West Pacific that intensifies or weakens anomalous warming (El Niño) or cooling (La Niña) of central and eastern Equatorial Pacific waters (Cera \& Ferraz, 2015). The processes that lead to warming of the tropical atmosphere and, consequently, the formation of ENSO, cause changes in the global climate due to changes in atmospheric circulation. In Brazil, this phenomenon causes extreme drought in the Northeast and severe rainfall in the South during the summer (Grimm et al., 2000; Zhou \& Lau, 1998; Cera \& Ferraz, 2015). Thus, this event has been acting as a hydrological flow driver, promoting irregular flood pulses in floodplain systems (Ward et al., 2002; Räsänen \& Kummu, 2013).

Changes in the rainfall regime generally alter the abiotic characteristics of aquatic ecosystems (Simôes et al., 2013a). In floodplain environments, during the period of extreme flood, the environments (i.e. rivers and lagoons) connect, leading to the homogenization of environmental variables (Thomaz et al., 2007; Bozelli et al., 2015). Consequently, these events influence the establishment of many species from aquatic communities (Maltchik et al., 2004; Pelicice et al., 2005; Lansac-Tôha et al., 2009).

Floodplains, especially those that retain their natural characteristics, usually have a high number of species and consequently support distinct trophic groups (Ximenes et al., 2011). The term "trophic groups" is a collection of species that exploit the same food resource (Root, 1967; Yodzis, 1982; Burns, 1989). Knowing the trophic pattern of a given environment is not only important for identifying the eating habits of organisms, but also for understanding the relationships between them as they connect and interact through their eating habits (Elliott et al., 2007). Thus, assessing trophic groups can function as an important tool for ecosystem monitoring and conservation, providing a description of the ecosystem's organization and functioning (Winemiller \& Jepsen, 1998).

In the upper Paraná River floodplain the zooplankton community is characterized by being highly diverse (Lansac-Tôha et al., 2009). Among the groups that make up this community, copepods are considered characteristic planktonic organisms and are an important link in the transfer of energy between trophic levels. Calanoids are basically herbivores and use small particles that are filtered by the arrows and setules found in their mouthparts (Matsumura-Tundisi \& Silva, 1999). In contrast, Cyclopoida are considered raptorial omnivores, as they have oral devices adapted to capturing larger particles (Matsumura-Tundisi \& Silva, 1999).

Admitting the importance of periods of extreme flood and drought in the functioning and dynamics of continental aquatic ecosystems, this study aimed to: (i) investigate which environmental variables have the greatest variation in the drought period (2000) and extreme flood (2010); (ii) whether environmental heterogeneity during these periods 
differs; and (ii) which variables are predictors of abundance of copepod trophic groups (omnivores and herbivores) in the extreme dry and flood years.

\section{Material and Methods}

\subsection{Study area}

The study was conducted on the upper Paraná River floodplain in the last dam-free stretch located between the downstream stretch from the Porto Primavera dam (São Paulo, Brazil) (22 37'S; 53 $\left.6^{\prime} \mathrm{W}\right)$ and the backwater of the Itaipu reservoir

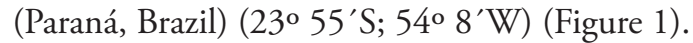

The upper Paraná River floodplain is an ecosystem characterized by seasonal periods of hydrological regime that allow the formation of various types of environments (Junk et al., 1989), including areas of floodplains that are fundamental for maintaining biodiversity (Ward et al., 2002). The flood pulse, in these environments, shows a typical seasonal dynamic throughout the year, since floods generally occur in the months of March and December. However, atypical variations occur because of longer periods of drought or flood, which are influenced, respectively, by La Niña and El Niño episodes (Grimm \& Tedeschi, 2009). Considering these events, it was possible to observe that the years (2000 and 2010) showed different flood dynamics, indicating that 2000 was an atypical dry period in which flood pulse attributes, such as the intensity and amplitude of inundation and connectivity index, were lower than in 2010 (Simóes et al., 2013a).

\subsection{Sample design}

In the floodplain study area, nine environments were sampled (i.e. rivers, tributaries channels, backwaters, tributaries, and temporary and permanent lakes), belonging to three sub-basins formed by the main river (Paraná River sub-basin) and two main tributaries (Baía and Ivinhema river basins) (Table 1). Zooplankton was collected in March and December of 2000 and 2010, months when climatic events were accentuated, and the copepod and rotifer were analyzed. During the studied months of 2000 the La Niña event took place, making the connectivity of the environments last 11 days. On the other hand, in the studied months of 2010, there was El Niño, increasing the connectivity time to 102 days.

The copepods and rotifers were sampled at the same time and sample, at the subsurface of the pelagic region of each aquatic environment $(36$ samples in total, March 2000/2010 and December 2000/2010), with a motor pump and plankton net $(68 \nabla \mathrm{m})$, and 600 liters of water per sample were filtered. The collected material was placed in

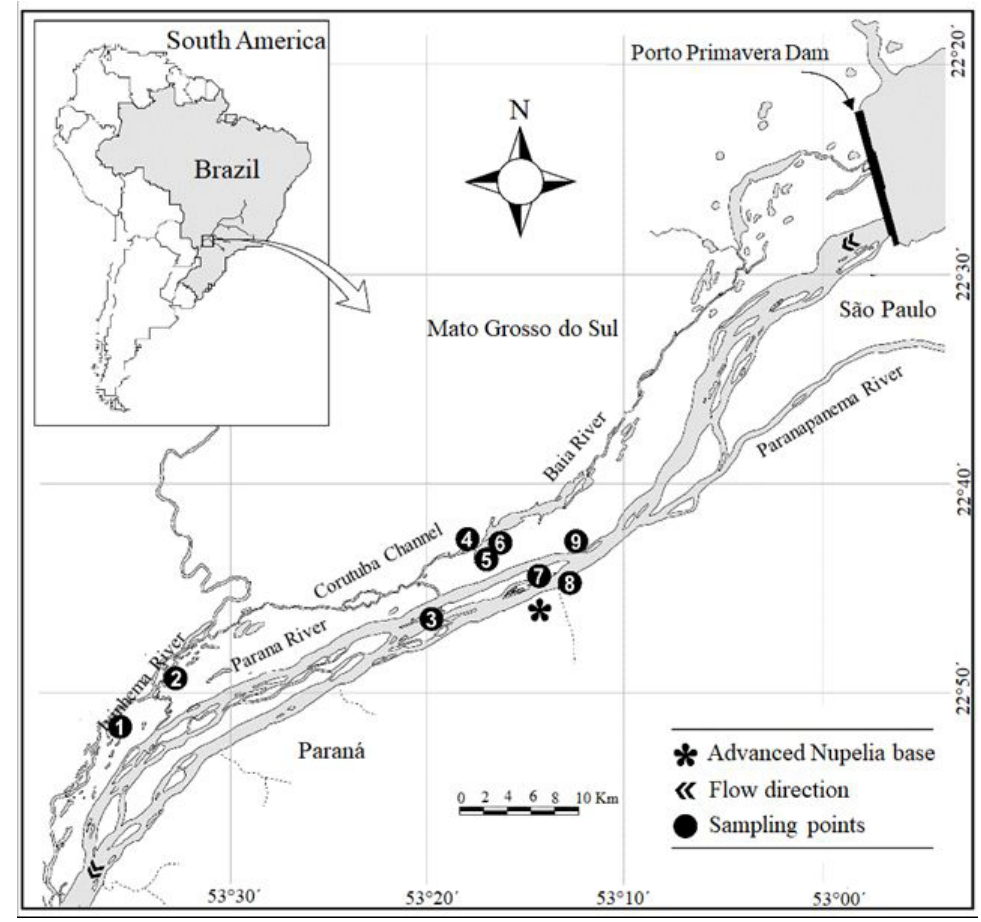

Figure 1. Sampling points of the high Paraná river floodplain in the Paraná sub-basin (PAR = Parana River, RES = Pau Véio Ressaco, GAR = Garças lake, OSM = Osmar lake, BAI= Baia river, GUA = Guarana lake and FEC $=$ Fechada lake) and Ivinhema (IVI = Ivinhema River; PAT = Patos lake; VEN=lakeVentura). 
Table 1. Environments studied in the high Paraná river floodplain, considering their environmental characteristics.

\begin{tabular}{|c|c|}
\hline Lakes & Environmental characterization \\
\hline & Paraná River sub-basin \\
\hline 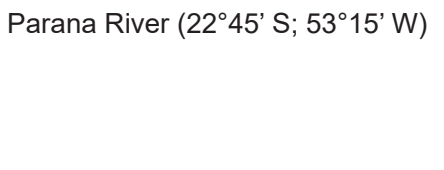 & $\begin{array}{c}\text { It presents varied width, with the presence of islands. Average depth: } 4.0 \\
\mathrm{~m} \text {. Maximum depth: } 15 \mathrm{~m} \text {. Vegetation composed of fields, the dikes being } \\
\text { occupied by sparse trees, remnants of the original vegetation. Occupied } \\
\text { areas occur along the left bank, Paraná. Some islands still have arboreal } \\
\text { vegetation, moderately explored. }\end{array}$ \\
\hline
\end{tabular}

Pau Véio ressaco (22 $44^{\prime} \mathrm{S}$; $\left.53^{\circ} 15^{\prime} \mathrm{W}\right) \quad$ Average depth: $1.8 \mathrm{~m}$ - area: 3.0 ha; communicates with the right bank of the Paraná River. Its length is $1,146.4 \mathrm{~m}$. On its right bank there are Ingás (Inga uruguensis) and pasture fields, in addition to Croton.

Garças Lake (2243' S; 53¹3' W)

Average depth: $2.03 \mathrm{~m}$ - area: $14.08 \mathrm{ha}$; it presents riparian forest in its surroundings and extensive multispecific banks of aquatic macrophytes in almost all its extension, with the predominance of Eichhornia azurea, and submerged macrophyte banks; it also presents communication with the river through a $5 \mathrm{~m}$ long winding channel.

Osmar Lake(22 $\left.46^{\prime} \mathrm{S} ; 5^{\circ} 19^{\prime} \mathrm{W}\right) \quad$ Average depth: $1.13 \mathrm{~m}$ - area: 0.006 ha; temporary lagoon located on an island in the gutter of the Paraná River, it presents terrestrial vegetation on its margin that prevents the action of the wind in the water column, and reduced banks of emerged and floating aquatic macrophytes; it has no communication with the river, and it is $100 \mathrm{~m}$ away from its channel.

\section{Baia River sub-basin}

Baia river $\left(22^{\circ} 43^{\prime} \mathrm{S} ; 53^{\circ} 17^{\prime} \mathrm{W}\right)$

Average depth: $3.2 \mathrm{~m}$. It has varied width and narrower stretches with higher dikes occupied by riparian vegetation or man-made fields. In the wider stretches, the dikes are lower and the vegetation consists of flooded fields (floodplain). Winding river and moderately lotic water. Sampling was carried out in wider areas, with less speed and with aquatic macrophytes and slopes occupied by grasses.

Guaraná Lake (2243’ S; 5318’ W)

Average depth: $2.06 \mathrm{~m}$ - area: $4.21 \mathrm{ha}$; it does not present riparian vegetation in its surroundings and it has extensive multispecific banks of aquatic macrophytes in almost all its extension, with the predominance of Eichhornia azurea. It also presents communication with the river through a short $70 \mathrm{~m}$ long channel.

Fechada Lake (2242’ S; 5316’ W)

Average depth: $2.46 \mathrm{~m}$ - area: $7.46 \mathrm{ha}$; absence of riparian forest in its surroundings, and reduced multispecific banks of aquatic macrophytes

on its banks, with the predominance of Eichhornia azurea. It has no

communication with the river and is $100 \mathrm{~m}$ away from its channel. However, during the flood period it connects with the river quickly due to the absence of a high slope on the river bank.

\section{Ivinhema river sub-basin}

Ivinhema River

Patos'Lake (2249' S; 533' W)

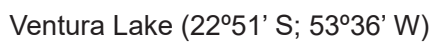

Average depth: $3.50 \mathrm{~m}$ - area: 113.80 ha; it does not present large extensions of riparian forest in its surroundings. It presents multispecific banks of aquatic macrophytes in some stretches of its banks, with the predominance of Eichhornia azurea, and communication with the river through an $8 \mathrm{~m}$ long winding channel.

Average depth: $2.16 \mathrm{~m}$ - area: 89.79 ha; it presents riparian forest in its surroundings and multispecific banks of aquatic macrophytes in some stretches of its banks, with the predominance of Eichhornia azurea. Has no communication with the river and is $200 \mathrm{~m}$ away from its gutter

Source: Souza-Filho \& Stevaux (2002).

properly labeled polyethylene bottles, fixed in 4\% formaldehyde solution and buffered with calcium carbonate.

At the same time as taking samples of organisms, depth, water temperature, dissolved oxygen, $\mathrm{pH}$, electrical conductivity, water transparency, total suspended material were measured in situ, and total nitrogen, nitrate, ammonia, total phosphorus, phosphate and chlorophyll-a were measured in the laboratory. Water temperature and dissolved oxygen were obtained in situ with an YSI portable digital oximeter with thermometer attached. The $\mathrm{pH}$ and conductivity were measured from portable digital potentiometers (Digimed $^{\oplus}$ ). Water transparency was determined with a $25 \mathrm{~cm}$ diameter Secchi disc. Total nitrogen and phosphate concentrations were determined according to Mackereth et al. (1978), and those of nitrate, ammonia and total phosphorus, according to Giné et al. (1980), Koroleff (1976) and Golterman et al. (1978), 
respectively. The concentration of total suspended material was determined by gravimetric method (Teixeira et al., 1965). Chlorophyll-a concentration was determined by filtration of water aliquots on glass fiber filters (Whatman GF/F), 90\% acetone pigment extraction, spectrophotometer reading $(663 \mathrm{~nm})$ and correction for other dissolved compounds and turbidity (Golterman et al., 1978).

\subsection{Zooplakton analysis}

Taxonomic identification of species was performed using the taxonomic keys of MatsumuraTundisi (1986), Santos-Silva (2000), LansacTôha et al. (2002) and Perbiche-Neves (2011). To estimate the abundance of individuals, subsamples were obtained with a Hensen-Stempell pipette $(2.5 \mathrm{~mL})$, and at least 50 individuals were counted in Sedgewick-Rafter chambers under an optical microscope according to the methodology of Bottrell et al. (1976) modified. However, those samples with a small number of individuals were analyzed in full. Total abundance of organisms was expressed in terms of individuals per cubic meter (ind $\mathrm{m}^{-3}$ ).

The classification of copepods into two trophic groups, obtained through the literature, was based on the type of food ingested by the organisms. According to the literature, Cyclopoida are omnivorous because they feed from bacteria to rotifers (Rietzler, 1995; Pompêo, 1999; Landa et al., 2007). However, Calanoids are herbivores, having a preference for phytoplankton (Pompêo, 1999). The rotifers, which are also part of the main diet of the omnivorous Copepoda, were collected and their abundance determined according to the same methodology used for copepods.

\subsection{Data analyses}

To check for differences in environmental variables between the months of March (2000 and 2010) and December (2000 and 2010) we performed the Student's t test $(\mathrm{p}<0.05)$. Besides that, we carried out the Permutational Analysis of Multivariate Dispersions (PERMDISP; Anderson et al., 2006) to detect if 2000 and 2010 had different levels of environmental heterogeneity. In order to verify which variables act as predictors of the abundance of trophic groups (i.e. omnivores and herbivores) of copepods in the dry and extreme flood years (covariate), a covariance analysis (ANCOVA) was carried out between the environmental variables and the abundance of these microcrustaceans in that time. The t-test, PERMIDISP and ANCOVA were made in $\mathrm{R}$ software (R Core Team, 2015) using the 'vegan' package (Oksanen et al., 2012).

\section{Results}

\subsection{Hydrological level}

Through the values of variation of hydrological level it was possible to observe that during the year 2010 (flood period) presented the highest level values, mainly for the month of March (8.6 meters), when compared to 2000 (dry period) (4.2 meters). In 2000, specifically in the month of March, short time intervals were observed in which the hydrological level showed high values (Figure 2).

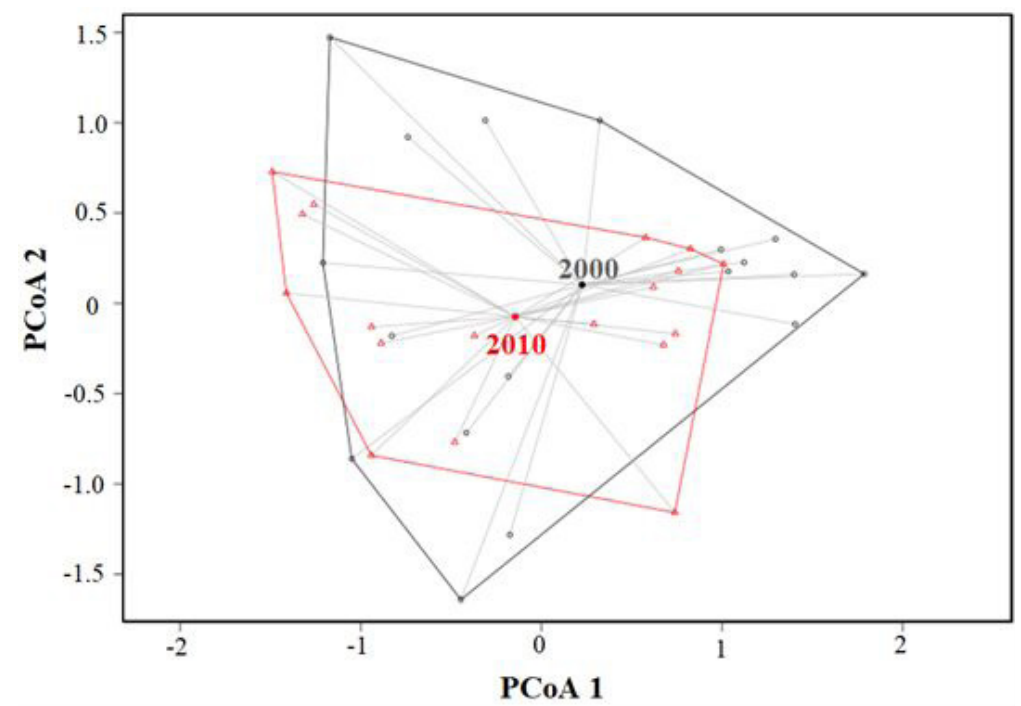

Figure 2. Dispersion of periods of drought and extreme flood (2000 and 2010) through PCoA (Principal Coordinate Analysis). The periods studied are identified by different colors. 


\subsection{Environmental Variables}

The environmental variables underwent great variations between the years studied (2000 and 2010) (Table 2). It was observed that the variables that showed significant differences between the months of March 2000 and 2010 ( $\mathrm{t}=230.27$; df=25; $\mathrm{p}=0.02)$ and December of 2000 and $2010(\mathrm{t}=178.8$; $\mathrm{df}=25 ; \mathrm{p}=0.01)$.

Considering the environmental heterogeneity, it was observed that the years studied (2000 and 2010) are significantly different $(\mathrm{F}=3.8 \mathrm{df}=1 ; \mathrm{gl}=5, p$ $=0.048)$, and the year of extreme drought (2000) was the most heterogeneous.

\subsection{Species composition and abundance}

In total, 15 copepod taxa were registered, being 10 omnivorous and five herbivores. Furthermore, 2000 was the year with the highest number of taxa (10 taxa) when compared to 2010 (six taxa) with omnivores the most representative in both years studied (Table 3).

The highest values of total copepod abundance were recorded in 2000. With respect to copepod trophic groups, the abundance varied over the years, with the maximum values obtained in 2000 for herbivores and in 2010 for omnivores. The most abundant species in 2000 were Notodiaptomus henseni (herbivores) and Thermocyclops decipiens (omnivores), whereas in 2010 it was Thermocyclops minutus (omnivores) (Table 3).

\subsection{Abundance of rotifers}

The abundance of rotifers varied between the years (2000 and 2010) studied. The highest value of abundance was found in December 2010 (8.7 $\mathrm{x} 10^{6}$ ind. $\left.\mathrm{m}^{-3}\right)$ and the lowest value in December $2000\left(8.5 \times 10^{4}\right.$ ind. $\left.\mathrm{m}^{-3}\right)$.

During the year 2000, which was extremely dry, the chlorophyll- $a$ and total phosphorus were considered the main predictors of herbivorous copepods abundance. The estimated parameters for the selected variables were significant $(\mathrm{p}<0.05)$ and are part of model, but the hydrological period (drought and flood) was not significant in our study. In considering omnivorous copepods, in 2000, it was possible to observe that rotifers were the main predictor of the abundance of these copepods. In 2010, herbivore and omnivores abundance were not related to the environmental variables studied (Table 4). In 2010 (extremely rainy), rotifers were considered the predictor responsible for copepod abundance.

\section{Discussion}

The results found in our study demonstrated that the extreme drought and flood events acted differently on the environmental conditions of the Upper Paraná River floodplain, since during extreme drought the environments were more heterogeneous when compared to the flood periods. Furthermore, it was possible to observe that trophic groups (i.e. herbivores and omnivores) are influenced by different variables.

According to the values of the hydrological level found in the floodplain, it was noted that the year 2010 presented higher values, mainly for the month of March, which is considered a rainy month, when compared to the year 2000. It is known that changes

Table 2. Environmental variables (Minimum, Maximum, Mean) recorded during of the months (March and December) of the years studied (2000 and 2010) in the high Paraná river floodplain.

\begin{tabular}{|c|c|c|}
\hline \multirow{3}{*}{ Environmental variables } & \multicolumn{2}{|c|}{ Years and study periods } \\
\hline & 2000 & 2010 \\
\hline & Mean (Min-Max) & Mean (Min-Max) \\
\hline Depth (m) & $2.6(0.95-5)$ & $3.8(0.8-9)$ \\
\hline Water temperature $\left({ }^{\circ} \mathrm{C}\right)$ & $23.2(17.7-29.8)$ & 26.05(22.3-29.6) \\
\hline Dissolved oxygen (mg L-1) & $7.2(1.5-10.87)$ & $5.9(0.18-9.64)$ \\
\hline $\mathrm{pH}$ & $6.6(5.73-8.85)$ & $7.08(6.23-8.52)$ \\
\hline Electrical Conductivity $\left(\mu \mathrm{S} \mathrm{cm}{ }^{-1}\right)$ & $44.7(24-50)$ & $47.9(22.3-70.2)$ \\
\hline Transparency (m) & $0.87(0.1-3.25)$ & $1.5(0.4-5.2)$ \\
\hline Total Suspension Material $\left(\mu \mathrm{g} \mathrm{L}^{-1}\right)$ & $7.01(1.1-27.2)$ & $2.43(0.33-10.7)$ \\
\hline Chlorophyll-a $\left(\mu \mathrm{g} \mathrm{L}^{-1}\right)$ & $10.4(0.0-89.5)$ & $8.39(0.41-50.2)$ \\
\hline Total Nitrogen $\left(\mu \mathrm{g} \mathrm{L}^{-1}\right)$ & $389.6(243-902.5)$ & $780.9(396.6-1768.6)$ \\
\hline Nitrate $\left(\mu \mathrm{g} \mathrm{L}^{-1}\right)$ & $73.5(0.0-229)$ & $68.3(0.0-216.86)$ \\
\hline Ammonia $\left(\mu \mathrm{g} \mathrm{L}^{-1}\right)$ & $9.4(0.0-37)$ & $14.2(0.0-82.59)$ \\
\hline Total Phosphorus ( $\left.\mu \mathrm{g} \mathrm{L}^{-1}\right)$ & $51.9(4.94-289.5)$ & $35.8(7.38-400.4)$ \\
\hline Phosphate $\left(\mu \mathrm{g} \mathrm{L}^{-1}\right)$ & $6.8(0.0-25.7)$ & $7.6(0.4-18.85)$ \\
\hline
\end{tabular}

${ }^{*}$ Min $=$ Minimum, Max $=$ Maximum. 
Table 3. List of copepod taxa and abundance $\left(\right.$ ind $\mathrm{m}^{-3}$ ) registered during the years and study periods in the floodplain of the upper Paraná River.

\begin{tabular}{|c|c|c|c|c|}
\hline \multirow{2}{*}{ Taxons } & \multicolumn{2}{|c|}{ Omnivores } & \multicolumn{2}{|c|}{ Herbivores } \\
\hline & 2000 (Drough) & 2010 (Flood) & 2000 (Drough) & 2010 (Flood) \\
\hline Argyrodiaptomus furcatus (Sars, 1901) & & & 333 & \\
\hline Eucyclops solitarius Herbst, 1959 & 251 & & & \\
\hline Eucyclops sp. & & & & \\
\hline Mesocyclops longisetus (Thiébaud, 1912) & & 2.7 & & \\
\hline Mesocyclops longisetus curvatus Dussart, 1987 & 3 & & & \\
\hline Mesocyclops meridianus (Kiefer, 1926) & 3,278 & 356.2 & & \\
\hline Mesocyclops ogunus Onabamiro, 1957 & & 51.9 & & \\
\hline Microcyclops anceps (Richard, 1897) & 266 & & & \\
\hline Notodiaptomus deitersi (Poppe, 1891) & & & & 49.1 \\
\hline Notodiaptomus henseni (Dahl, 1894) & & & 56,011 & \\
\hline Notodiaptomus iheringi (Wright, 1935) & & & 1,309 & \\
\hline Notodiaptomus cf. spinuliferus (Dussart, 1986) & & & 4.9 & \\
\hline Paracyclops sp. & & 2 & & \\
\hline Thermocyclops decipiens (Kiefer, 1929) & 9,167 & 4,552 & & \\
\hline Thermocyclops minutus (Lowndes, 1934) & 5,189 & 26,717 & & \\
\hline Total & 18,143 & 31,691 & 62.6 & 49.1 \\
\hline
\end{tabular}

Table 4. Summary of covariance analysis between abundance of herbivorous copepods and environmental variables.

\begin{tabular}{|c|c|c|c|c|c|}
\hline Year/ Trophic group & Model equation & $\mathbf{R}^{2}$ adjusted & $\mathbf{F}$ & $\mathbf{N}$ & $P$ \\
\hline 2000/ Herbivores & $\begin{array}{c}\text { Abh00 }=0.0016^{*} \text { chlorophyll-a }+0.03370^{*} \\
\text { Total phosphorus }\end{array}$ & 0.99 & 42.6 & 35 & $<0.01$ \\
\hline 2000/ Omnivores & Abo $10=0.0451^{*}$ rotifers (abundance) & 0.64 & 31.5 & 27 & $<0.01$ \\
\hline
\end{tabular}

${ }^{*} \mathrm{Abh}=$ Abundance of herbivores; $\mathrm{Abo}=$ Abundance of omnivores.

in the hydrological regime cause drastic changes in the environmental variables of environments (Thomaz et al., 2007; Simóes et al., 2013b). In addition to directly or indirectly influencing the structuring of aquatic communities, such as biotic interactions and species distribution (Dunson \& Travis, 1991; Schwind et al., 2016). In floodplains, the phases of hydrologic cycle have different duration periods and very distinct characteristics, which provide specific conditions for the existence of certain organisms (Junk et al., 1989). In this context, it is believed that changes in environmental conditions, provided by the atypical years of drought and extreme flood, may reflect changes in the structure of trophic groups of copepods in floodplain environments, as it can alter its attributes such as abundance and species richness (Alho \& Sabino., 2012).

In addition, it was possible to observe that the months sampled in the year 2000 showed greater environmental heterogeneity than in 2010. Many authors have demonstrated that environments subjected to periods of extreme drought (such as La Niña events) have greater environmental heterogeneity (Thomaz et al., 2007; Melo \& Medeiros, 2013; Datry et al., 2014). This can be justified by the fact that in the drier periods, habitats are more isolated from each other, causing local forces (e.g. environmental conditions) to act with different intensities in each environment (Bozelli et al., 2015; Dias et al., 2016).

The greatest number of species and highest abundance values for copepods were recorded in the periods of extreme drought in 2000. According to Simóes et al. (2012), the hydrological level in environments is closely related to the dynamics of zooplanktonic community. Corroborating our results, other studies carried out in floodplains also found the highest number of species and zooplanktonic abundance during dry periods (Lansac-Tôha et al., 1993; Rossa \& Bonecker, 2003; Henry et al., 2011).

The herbivores were more abundant in the period of extreme drought and omnivores in the flood. In periods of extreme drought, hydrodynamic conditions were more stable, thus promoting primary productivity, represented by algae, which support large populations of zooplanktonic organisms due to their longer residence time in water (Baranyi et al., 2002), especially those that feed on these organisms, such as herbivorous copepods. On the other hand, in extreme floods, environmental conditions are disadvantageous for the development of large populations of algae due 
to greater hydrodynamic instability, which can lead to a decrease in the organisms that feed on them (Baranyi et al., 2002). Furthermore, as expected in our study, the greatest abundance values for $N$. henseni (herbivores), T. minutus (omnivores), and T. decipiens (omnivores), have often been found in freshwater ecosystems (Ferrareze \& Nogueira, 2011), mainly in the floodplain of the upper Paraná River (Lansac-Tôha et al., 2004; 2009; Palhiarini et al., 2017).

The chlorophyll-a and total phosphorus, considered as parameters of productivity, had a strong positive relationship with the abundance of herbivorous copepods during 2000. These results corroborate those found in the same study area (Simóes et al., 2012), in reservoirs (Brito et al., 2016), and on the Danube river floodplain (Kiss et al., 2014). According to Bastidas-Navarro \& Modenutti (2007), variations in the concentration of chlorophyll-a (proxy to algal biomass) contribute to the availability of food resources and, consequently, to the distribution of aquatic organisms (Mantovano et al., 2019). This relationship may be justified since herbivorous copepods preferentially feed on small phytoplankton organisms with high nutritional value (Câmara et al., 2014). Total phosphorus concentrations also contributed to explaining the variation in abundance in the herbivorous copepod community in the period of extreme drought. The higher concentration of this nutrient in the aquatic environment provides an increase in plankton primary productivity (Bonecker et al., 2013), which may indicate an indirect influence on the abundance of herbivorous copepods in these environments (Perbiche-Neves et al., 2007; Mantovano et al., 2019). These results corroborate those found in a study developed in 20 lakes in Central Amazonia (Trevisan \& Forsberg, 2007).

Still in 2000, omnivorous copepods had a positive relationship with rotifer abundance. This relationship may be associated with the fact that omnivorous copepods, such as cyclopoids, have a broad food spectrum with raptorial habit (Perbiche-Neves et al., 2014). According to Brandl, (2005), due to their small size and restricted mobility, rotifers are considered as the preferred food items in the diet of omnivorous species. In drought periods, such as in 2000, environments become more isolated and influenced mainly by local forces such as resource availability (Thomaz et al., 2007, Simóes et al., 2012), making environments more heterogeneous. This may justify the positive relationship, found in our study, with the abundance of copepod trophic groups. On the other hand, in 2010, considered as extreme flood, no variable showed a significant relationship with the abundance of herbivorous and omnivorous copepods. It is known that in the period of extreme flooding the flood pulse provides the exchange of biota, particulate matter and nutrients between the environments, reducing the environmental heterogeneity (Thomaz et al., 2007; Bozelli et al., 2015) and, consequently, the amount and quality of food resources available for the maintenance of species (Tilman, 1982) such as copepods.

Our study was carried out in two hygrologically atypical periods years on a floodplain. Our results showed that environmental variables differ between years and that periods of extreme drought showed greater environmental heterogeneity. In general, it is believed that in periods of extreme drought the variables associated with productivity act as determining forces on the abundance of trophic groups of copepods due to the contraction of aquatic ecosystems. Although the abundance of trophic groups is associated with system productivity, the responses between them differ because herbivore abundance is associated with chlorophyll- $a$ and total phosphorus and omnivores with rotifer abundance. The high abundance of omnivores implies the absence of competition between them for food resources in periods of extreme drought. According to our results, we believe that the increase in hydrological regime changes, intensified by the growing effects of climate change, may alter the copepod community, since they are organisms that are highly sensitive to environmental changes. Furthermore, because they are organisms that represent an energy link between producers and other consumers, they can change countless aquatic communities.

\section{Acknowledgements}

We thank the Centre of Research in Limnology, Ichthyology and Aquaculture (Núcleo de Pesquisas em Limnologia, Ictiologia e Aquicultura - Nupélia) and Programa de Pós-Graduação em Ecologia de Ambientes Aquáticos Continentais - PEA of State University of Maringá (Universidade Estadual de Maringá - UEM) for the logistic support. We would like to thanks CAPES and CNPq for the scholarship and productivity grant. 


\section{References}

ALHO, C.J. AND SABINO, J. Seasonal Pantanal flood pulse: implications for biodiversity. Oecologia Australis, 2012, 16(4), 958-978.

AGOSTINHO, A.A., GOMES, L.C., VERÍSSIMO, S. and OKADA, E.K. Flood regime, dam regulation and fish in the Upper Paraná River: effects on assemblage attributes, reproduction and recruitment. Reviews in Fish Biology and Fisheries, 2004, 14(1), 11-19. http:// dx.doi.org/10.1007/s11160-004-3551-y.

ANDERSON, M.J., GORLEY, R.N. and CLARKE, K.R. PERMANOVAp for PRIMER: Guide to software and statistical methods. Plymouth, UK: PRIMER-E, 2006.

BARANYI, C., HEIN, T., HOLAREK, C., KECKEIS, S. and SCHIEMER, S. Zooplankton biomass and community structure in a Danube River floodplain system: effects of hydrology. Freshwater Biology, 2002, 47(3), 473-482. http://dx.doi.org/10.1046/j.13652427.2002.00822.x.

BRANDL, Z. Freshwater copepods and rotifers: predators and their prey. Hydrobiologia, 2005, 546(1), 475-489. http://dx.doi.org/10.1007/s10750-005-4290-3.

BASTIDAS-NAVARRO, M. and MODENUTTI, B. Effect of macrophytes and food resources on the horizontal distribution of testate amoebae and rotifers in an Andean-Patagonian lake. Revista Chilena de Historia Natural, 2007, 80(3), 345-362. http:// dx.doi.org/10.4067/S0716-078X2007000300008.

BONECKER, C.C., SIMÓES, N.R., MINTE-VERA, C.V., LANSAC-TÔHA, F.A., VELHO, L.F.M. and AGOSTINHO, A.A. Temporal changes in zooplankton species diversity in response to environmental changes in an alluvial valley. Limnologica, 2013, 43(2), 114-121. http://dx.doi. org/10.1016/j.limno.2012.07.007.

BOTTRELL, H.H., DUNCAN, A., GLIWICZ, Z.M., GRYIEK, E., HERZIG, A., HILLBRICHTILKOWSKA, A., KURASAWA, H., LARSSON, P. and WEGLENSKA, T. A review of some problems in zooplankton production studies. Norwegian Journal of Zoology, 1976, 24(1), 419-456.

BOZELLI, R.L., THOMAZ, S.M., PADIAL, A.A., LOPES, P.M. and BINI, L.M. Floods decrease zooplankton beta diversity and environmental heterogeneity in an Amazonian floodplain system. Hydrobiologia, 2015, 753(1), 233-241. http://dx.doi. org/10.1007/s10750-015-2209-1.

BRITO, S.L., MAIA-BARBOSA, P.M. and PINTOCOELHO, R.M. Secondary productivity of main microcrustacean species of two tropical reservoirs in Brazil and its relationship with trophic state. Journal of Limnology, 2016, 75(2), 320-329. http://dx.doi. org/10.4081/jlimnol.2016.1267.
BURNS, T.P. Lindman's contradiction and the trophic structure of ecosystems. Ecology, 1989, 70(1), 13551362. http://dx.doi.org/10.2307/1938195.

CÂMARA, F.R.A., PESSOA, E.K.R., SANTOS, L.L.S., ROCHA, O., CHELLAPPA, S. and CHELLAPPA, N.T. Influência da alimentação na taxa de sobrevivência e desenvolvimento de Notodiaptomus cearenses Wright, 1936 (Crustacea: Copepoda) e Physiocypria schubarti Farkas, 1958 (Crustacea: Ostracoda). Biota Amazônia, 2014, 4(2), 43-50. http://dx.doi.org/10.18561/2179-5746/ biotaamazonia.v4n2p43-50.

CERA, J.C. and FERRAZ, S.E.T. Variações climáticas na precipitação no Sul do brasil no clima presente e futuro. Revista Brasileira de Meteorologia, 2015, 30(1), 81-88. http://dx.doi.org/10.1590/0102778620130588 .

DATRY, T., LARNED, S.T. and TOCKNER, K. Intermittent rivers: a challenge for freshwater ecology. Bioscience, 2014, 64(3), 229-235. http://dx.doi. org/10.1093/biosci/bit027.

DIAS, J.D., SIMÓES, N.R., MEERHOFF, M., LANSAC-TÔHA, F.A., VELHO, L.F.M. and BONECKER, C.C. Hydrological dynamics drives zooplankton metacommunity structure in a Neotropical floodplain. Hydrobiologia, 2016, 781(1), 109-125. http://dx.doi.org/10.1007/s10750-0162827-2.

DUNSON, W.A. and TRAVIS, J. The role of abiotic factors in community organization. American Naturalist, 1991, 138(1), 1067-1091. http://dx.doi. org/10.1086/285270.

ELLIOTT, M., WHITFIELD, A.K., POTTER, I., BLABER, S.J.M., CYRUS, D.P., NORDLIE, F.G. and HARRISON, T.D. The guild approach the categorizing estuarine fsh assemblages: a global review. Fish and Fisheries, 2007, 8(3), 241-268. http://dx.doi. org/10.1111/j.1467-2679.2007.00253.x.

FERRAREZE, M. and NOGUEIRA, M.G. Importância das lagoas laterais para as assembléias de zooplâncton (Cladocera e Copepoda) em um grande reservatório tropical. Oecologia Australis, 2011, 15(3), 522-536. http://dx.doi.org/10.4257/oeco.2011.1503.07.

GINÉ, M.F., BERGAMIN, F., ZAGATTO, E.A.G. and REIS, B.F. Simultaneous determination of nitrate and nitrite by flow injection analysis. Acta Analytica Chimica, 1980, 114(1), 191-197. http://dx.doi. org/10.1016/S0003-2670(01)84290-2.

GOLTERMAN, H.L., CLYMO, R.S. and OHMSTAD, M.A.M. Methods for physical and chemical analyses of freshwaters. Oxford: Blackwell Scientific Publication, 1978, 213 p.

GRIMM, A.M., BARROS, V.R. and DOYLE, M.E. Climate variability in southern South America associated with El Nino and La Nina events. Journal of Climate, 2000, 13(1), 35-58. http://dx.doi. 
org/10.1175/1520-0442(2000)013<0035:CVISSA $>2.0 . \mathrm{CO} ; 2$.

GRIMM, A.M. and TEDESCHI, R.G. ENSO and extreme rainfall events in South America. Journal of Climate, 2009, 22(7), 1589-1609. http://dx.doi. org/10.1175/2008JCLI2429.1.

HENRY, R., PANARELLI, E.A., CASANOVA, S.M.C., GRANADO, D.C., MORTARI, R.C. and ABRA, J. Plankton richness and abundance in several different hydrological situations in lakes lateral to a river: a case study in the mouth zone of a tributary into a tropical Reservoir. Oecologia Australis, 2011, 15(3), 537-558. http://dx.doi.org/10.4257/oeco.2011.1503.08.

JUNK, W.J., BAYLEY, P.B. and SPARKS, R.E. The flood pulse concept in river-floodplain systems. Canadian Journal of Fisheries and Aquatic, 1989, 106, 110-127.

KISS, A., ÁGOSTON-SZABÓ, E., DINKA, M., SCHÖLL, K. and BERCZIK, Á. Microcrustacean (Cladocera, Copepoda, Ostracoda) diversity in three side arms in the Gemenc Floodplain (Danube River, Hungary) in different hydrological situations. Acta Zoologica Bulgarica, 2014, 7, 135-141.

KOROLEFF, K.J.H. Determination of ammonia. In: E. GRASSHOFF and E. KREMLING, eds. Methods of seawater analysis. New York: Verlag Chemie Wheinhein, 1976, pp.117-181.

LANDA, G.G., BARBOSA, F.A.R., RIETZLER, A.C. and MAIA-BARBOSA, P.M. Thermocyclops decipiens (Kiefer, 1929) (Copepoda, Cyclopoida) as indicator of water quality in the State of Minas Gerais. Brazilian Archives of Biology and Technology, 2007, 50(1), 695-705. http://dx.doi.org/10.1590/S151689132007000400015.

LANSAC-TÔHA, F. A., LIMA, A., THOMAZ, S. M. and ROBERTO, M. C. Zooplâncton de uma planície de inundação do rio Paraná. II. Variação sazonal e influência dos níveis fluviométricos sobre a comunidade. Acta Limnologica Brasiliensia, 1993, 6, 42-55.

LANSAC-TÔHA, F.A., VELHO, L.F.M., HIGUTI, J. and TAKAHASHI, E.M. Cyclopidae (Crustacea, Copepoda) from the upper Paraná river floodplain. Brazilian Journal of Biology $=$ Revista Brasileira de Biologia, 2002, 62(1), 125-133. http://dx.doi. org/10.1590/S1519-69842002000100015. PMid:12185912.

LANSAC-TÔHA, F.A., BONECKER, C.C., VELHO, L.F.M., TAKAHASHI, E.M. and NAGAE, M.Y. Zooplancton na planície de inundação do alto rio Paraná: composição, riqueza, abundância e relaçóes com o nivel hidrológico e a conectividade. In: A.A. AGOSTINHO, L. RODRIGUES, L.C. GOMES, S.M. THOMAZ and L.E. MIRANDA, orgs. Estrutura e funcionamento do rio Paraná e sua planície de inundação. Maringá: Eduem, 2004, pp. 75-84
LANSAC-TÔHA, F.A., BONECKER, C.C., VELHO, L.F.M., SIMÓES, N.R., DIAS, J.D., ALVES, G.M. and TAKAHASHI, E.M. Biodiversity of zooplankton communities in the Upper Paraná River floodplain: interannual variation from long-term studies. Brazilian Journal of Biology $=$ Revista Brasileira de Biologia, 2009, 69(2, Suppl), 539-549. http:// dx.doi.org/10.1590/S1519-69842009000300009. PMid:19738961.

MACKERETH, F.J.H., HERON, J. and TALLING, J.F Water analysis: some revised methods for limnologists. In: J. GAUDET, ed. The Quarterly Review of Biology, 1978, vol. 54, no. 2, 203 p. http://dx.doi. org/10.1086/411247.

MALTCHIK, L., ROLON, A.S., GUADAGNIN, D.L. and STENERT, C. Wetlands of Rio Grande do Sul, Brazil: a classification with emphasis on plant communities. Acta Limnologica Brasiliensia, 2004, 16(2), 137-151.

MANTOVANO, T., BRAGHIN, L.S.M., SCHWIND, L.T.F., TIBÚRCIO, V.G., BONECKER, C.C. and LANSAC-TÔHA, F.A. Zooplankton communities show contrasting productivity variables thresholds in dammed and undammed systems. Limnetica, 2019, 38(2), 669-682. http://dx.doi.org/10.23818/ limn.38.39.

MATSUMURA-TUNDISI, T. and SILVA, W.M. Crustáceos copépodos planctônicos. In: C.A. JOLY and C.E.M. BICUDO, orgs. Biodiversidade do Estado de São Paulo, Brasil: Sintese do conhecimento ao final do século XX. Invertebrados de Água Doce, 1999, pp. 91-100. São Paulo: FAPESP. vol. 4.

MATSUMURA-TUNDISI, T. Latitudinal distribution of Calanoida in freshwater aquatic systems of Brazil. Brazilian Journal of Biology, 1986, 46(1), 527-553.

MELO, T.X. and MEDEIROS, E.S.F. Spatial distribution of zooplankton diversity across temporary pools in a semiarid intermittent river. International Journal of Biodiversity, 2013, 2013, 1-13. http://dx.doi. org/10.1155/2013/946361.

OKSANEN, J., BLANCHET, F.G. and KINDT, R. Vegan: Community Ecology Package. R package version 2.0-6, 2012. [viewed 20 Jan. 2020]. Available from: http://vegan.r-forge.r-project.org/

PALHIARINI, W.S., SCHWIND, L.T.F., ARRIEIRA, R.L., VELHO, L.F.M. and LANSAC-TÔHA, F.A. Copepod assemblage structure (Crustacea: Copepoda) along a longitudinal environmental gradient in a tropical river-floodplain system, Brazil. Acta Limnologica Brasiliensia, 2017, 29, 1-16. http:// dx.doi.org/10.1590/s2179-975x0117.

PELICICE, F.M., AGOSTINHO, A.A. and THOMAZ, S.M. Fish assemblages associated with Egeria in a tropical reservoir: investigating the effects of plant biomass and diel period. Acta Oecologica, 2005, 27(1), 9-16. http://dx.doi.org/10.1016/j. actao.2004.08.004. 
PERBICHE-NEVES, G., NOGUEIRA, M.G., OLIVEIRA, P. and SERAFIM-JÚNIOR, M. Sobre alguns atributos ecológicos de copépodes (Crustacea) planctônicos de dois reservatórios profundos. Brazilian Journal of Aquatic Science and Technology, 2014, 18(1), 1-8. http://dx.doi.org/10.14210/bjast. v18n1.p1-8.

PERBICHE-NEVES, G. Copépodes planctônicos (Crustacea, Calanoida e Cyclopoida) em reservatórios e trechos lóticos da bacia do rio da Prata (Brasil, Paraguai, Argentina e Uruguai): taxonomia, distribuição geográfica e alguns atributos ecológicos [Tese de doutorado]. Botucatu: Departamento de Ciências Biológicas, Universidade Estadual Paulista, 2011, $238 \mathrm{p}$.

PERBICHE-NEVES, G., SERAFIM-JUNIOR, M., GHIDINI, A.R. and BRITO, L. Spatial and temporal distribution of Copepoda (Cyclopoida and Calanoida) of an eutrophic reservoir in the basin of upper Iguaçu river, Paraná, Brazil. Acta Limnologica Brasiliensia, 2007, 19(4), 393-406.

POMPÊ, M.L.M. Perspectivas na Limnologia do Brasil. São Luís: Gráfica e Editora União, 1999, 198 p.

RÄSÄNEN, T. and KUMMU, M. Spatiotemporal influences of ENSO on precipitation and flood pulse in the Mekong River Basin. Journal of Hydrology (Amsterdam), 2013, 476(7), 154-168. http://dx.doi. org/10.1016/j.jhydrol.2012.10.028.

R CORE TEAM R: A language and environment for statistical computing. Vienna: R Foundation for Statistical Computing, 2015 [viewed 20 Jan. 2020]. Available from: http://www.R-project.org/

RIETZLER, A.C. Alimentação, ciclo de vida e análise da coexistência de espécies de Cyclopoida na Represa de Barra Bonita, São Paulo [Tese de doutorado]. São Carlos: Escola de Engenharia de São Carlos, Universidade de São Paulo, 1995, 385 p.

ROOT, R.B. The niche exploitation pattern of the bluegray gnatcatcher. Ecological Monographs, 1967, 37(1), 317-350. http://dx.doi.org/10.2307/1942327.

ROSSA, D. and BONECKER, C.C. Abundance of planktonic and non-planktonic rotifers in lagoons of the Upper Paraná River floodplain. Amazoniana, 2003, 17, 567-581.

SANTOS-SILVA, E.M. Revisão das espécies do "complexo nordestinus" (Wright, 1935) de Notodiaptomus Kiefer, 1936 (Copepoda: Calanoida: Diaptomidae) [Tese de doutorado]. São Paulo: Departamento de Zoologia, Universidade de São Paulo, 2000, 198 p.

SCHWIND, L.T.F., ARRIEIRA, R.L., MANTOVANO, T., BONECKER, C.C. and LANSAC-TOHA, F.A. Temporal influence on the functional traits of testate amoebae in a floodplain lake. Limnetica, 2016, 35(2), 355-364. http://dx.doi.org/10.23818/limn.35.28.

SIMÓES, N.R., LANSAC-TÔHA, F.A., VELHO, L.F.M. and BONECKER, C.C. Intra and inter- annual structure of zooplankton communities in floodplain lakes: a long-term ecological research study. Revista de Biología Tropical, 2012, 60(4), 1819 1836. http://dx.doi.org/10.15517/rbt.v60i4.2183. PMid:23342531.

SIMÓES, N.R., LANSAC-TÔHA, F.A. and BONECKER, C.C. Drought disturbances increase temporal variability of zooplankton community structure in floodplains. International Review of Hydrobiology, 2013a, 98(1), 24-33. http://dx.doi. org/10.1002/iroh.201201473.

SIMÓES, N.R., DIAS, J.D., LEAL, C.M., BRAGHIN, L.S.M., LANSAC-TÔHA, F.A. and BONECKER, C.C. Floods control the influence of environmental gradients on the diversity of zooplankton communities in a neotropical floodplain. Aquatic Sciences, 2013b, 75(4), 607-617. http://dx.doi.org/10.1007/s00027013-0304-9.

SOUZA-FILHO, E.E. and STEVAUX, J.C. Locais de amostragem. In: A.A. AGOSTINHO, S.M. THOMAZ, K. NAKATANI, H.F. JÚLIO JÚNIOR, R.R. ANTÔNIO, K.D.G. LUZ, F.C. ZAVADSKI and J.L.L. PEREIRA, eds. A planície alagável do alto rio Paraná: estrutura e processos ambientais. Maringá, 2002, pp. 7-13. Relatório Técnico PELD/CNPq.

STENSETH, N.C., OTTERSEN, G., HURRELL, J.W., MYSTERUD, A., LIMA, M., CHAN, K.S., YOCCOZ, N. and ÅDLANDSVIK, B. Studying climate effects on ecology through the use of climate indices: The North Atlantic Oscillation, El Nino Southern Oscillation and beyond. Proceedings of the Royal Society of London, 2003, 134(1), 1-10. http://dx.doi.org/10.1098/rspb.2003.2415. PMid:14561270.

TEIXEIRA, C., TUNDISI, J.G. and KUTNER, M.B. Plankton studies in a mangrove, II: The standingstock and some ecological factors. Boletim do Instituto Oceanográfico, 1965, 14(1), 23-41. http://dx.doi. org/10.1590/S0373-55241965000100002.

THOMAZ, S.M., BINI, L.M. and BOZELLI, R.L. Floods increase similarity among aquatic habitats in river-floodplain systems. Hydrobiologia, 2007, 579(1), 1-13. http://dx.doi.org/10.1007/s10750006-0285-y.

TILMAN, D. Resource competition and community structure. Monographs in Population Biology, 1982, 17, 1-296. http://dx.doi.org/10.4319/ lo.1983.28.5.1043. PMid:7162524.

TOCKNER, K., MALARD, F. and WARD, J.V. An extension of the flood pulse concept. Hydrological Processes, 2000, 14(16-17), 2861-2883. http://dx.doi.org/10.1002/10991085(200011/12)14:16/17<2861::AIDHYP124>3.0.CO;2-F.

TREVISAN, G.V. and FORSBERG, B.R. Relationships among nitrogen and total phosphorus, algal biomass and zooplankton density in the central Amazonia 
lakes. Hydrobiologia, 2007, 586(1), 357-365. http:// dx.doi.org/10.1007/s10750-007-0705-7.

TUNDISI, J.G. and MATSUMURA-TUNDISI, T. Limnologia. São Paulo: Oficina de Textos, 2008 pp. 632.

WARD, J.V., TOCKNER, K., ARSCOTT, D.B. and CLARET, C. Riverine landscape diversity. Freshwater Biology, 2002, 47(4), 517-539. http://dx.doi. org/10.1046/j.1365-2427.2002.00893.x.

WINEMILLER, K.O. and JEPSEN, D.B. Effects of seasonality and fish movement on tropical river food webs. Journal of Fish Biology, 1998, 53(sA), 267296. http://dx.doi.org/10.1111/j.1095-8649.1998. tb01032.x.

XIMENES, L.Q.L., MATEUS, L.A.I. and PENHA, J.M.F. Variaçâoo temporal e espacial na composiçâo de guildas alimentares da iciofauna em lagoas marginais do Rio Cuiabá, pantanal Norte. Biota Neotropica, 2011, 11(1), 205-215. http://dx.doi.org/10.1590/ S1676-06032011000100022.

YODZIS, P. The compartmentation of real and assembled ecosystems. American Naturalist, 1982, 120(4), 551570. http://dx.doi.org/10.1086/284013.

ZHOU, J. and LAU, K.M. Does a monsoon climate exist over South America? Journal of Climate, 1998, 11(5), 1020-1040. http://dx.doi.org/10.1175/15200442(1998)011<1020:DAMCEO>2.0.CO;2.

Received: 20 January 2020 Accepted: 04 July 2020

Associate Editor: Luiz Ubiratan Hepp. 